\title{
Flexivirga alba gen. nov., sp. nov., an actinobacterial taxon in the family Dermacoccaceae
}

\author{
Kozue Anzai ${ }^{1}$, Tomoyasu Sugiyama ${ }^{2}$, Mayuko Sukisaki $^{1}$, Yayoi Sakiyama ${ }^{1}$, Misa Otoguro ${ }^{1}$ and Katsuhiko Ando ${ }^{1}$ \\ A novel actinobacterial strain $\mathrm{ST} 13^{\mathrm{T}}$ isolated from soil near wastewater treatment facilities of an electroplating plant was \\ subjected to a polyphasic taxonomic study. Cells of this organism were non-sporulating, and were irregular coccoid to comma \\ shaped. The peptidoglycan of strain ST13 ${ }^{\top}$ contained glutamic acid, serine, alanine, glycine and lysine, and represented the \\ peptidoglycan type $A 4 \alpha$. The whole-cell sugars contained ribose, glucose, galactose, rhamnose and mannose. The predominant \\ menaquinone was MK-8 $\left(\mathrm{H}_{4}\right)$. The major fatty acid was iso- $\mathrm{C}_{16: 0}$. The polar lipid contained phosphatidylglycerol. The DNA G+C \\ content was $67.4 \mathrm{~mol} \%$. Phylogenetic analysis based on 16S rRNA gene sequences revealed that strain ST13 ${ }^{\top}$ fell within

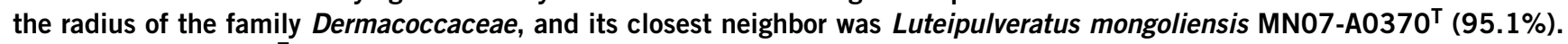 \\ However, strain ST $13^{\mathrm{T}}$ did not make a coherent clade with members of the recognized organisms. On the basis of the \\ phylogenetic and phenotypic characteristics of this actinobacterium, a novel genus and species, Flexivirga alba gen. nov., \\ sp. nov., is proposed. The type strain of $F$. alba is $\mathrm{ST}^{1} 3^{\top}\left(=\mathrm{NBRC} 107580^{\top}=\mathrm{DSM} 24460^{\top}\right)$.
}

The Journal of Antibiotics (2011) 64, 613-616; doi:10.1038/ja.2011.62; published online 3 August 2011

Keywords: actinobacteria; Dermacoccaceae; Flexivirga alba gen. nov., sp. nov.; new genus

\section{INTRODUCTION}

The family Dermacoccaceae was first proposed by Stackebrandt and Schumann, ${ }^{1}$ and its pattern of $16 \mathrm{~S}$ rRNA signature nucleotides was emended by Zhi et al. ${ }^{2}$ At the time of writing, the family Dermacoccaceae comprised of six recognized genera: Dermacoccus, ${ }^{3}$ Demetria, ${ }^{4}$ Kytococcus, ${ }^{3}$ Luteipulveratus, ${ }^{5}$ Yimella $^{6}$ and Branchiibius. ${ }^{7}$ The organisms belonging to these genera are Gram-positive, aerobic, non-halophilic, coccoid actinobacteria, and their peptidoglycan type is variation $\mathrm{A} 4 \alpha$. Isolates assigned to this family are typically associated with terrestrial habitats, notably, cured meat products, skin, human blood and soil. ${ }^{8-11}$ The recently described Branchiibius hedensis was isolated from the branchia of a codfish. ${ }^{7}$ During a study of aerobic bacteria from soil samples, we isolated a novel actinobacterium, designated $\mathrm{ST} 13^{\mathrm{T}}$, from soil near wastewater treatment facilities of an electroplating plant in Seki, Gifu prefecture, Japan. Phylogenetic analysis based on 16S rRNA gene sequence of strain $\mathrm{ST} 13^{\mathrm{T}}$ revealed that the isolate was a member of the suborder Micrococcineae. The aim of this study was to determine the taxonomic position of strain $\mathrm{ST} 13^{\mathrm{T}}$ by using a polyphasic approach.

\section{MATERIALS AND METHODS}

\section{Isolation and cultivation}

The soil sample was collected from a depth of $\sim 2 \mathrm{~cm}$ from the surface near the wastewater treatment facilities of an electroplating plant in Seki, Gifu prefecture, Japan. The sample was dried at room temperature for several days and suspended in $10 \mathrm{ml}$ sterile water. The sample was vortexed, allowed to settle for $1 \mathrm{~min}$, and $100 \mu \mathrm{l}$ of the resultant solution was further diluted and spread onto International Streptomyces Project (ISP) medium $2 .{ }^{12}$ The plates were incubated at $28^{\circ} \mathrm{C}$ for 1 week. The strain $\mathrm{ST} 13^{\mathrm{T}}$ was obtained after three successive transfers on yeast extract-soluble starch medium (YS medium; $2 \mathrm{~g}$ yeast extract, $10 \mathrm{~g}$ soluble starch and $15 \mathrm{gl}^{-1}$ agar; $\mathrm{pH}$ 7.3) and maintained as pure culture at room temperature until used. For long-term preservation, strain $\mathrm{ST} 13^{\mathrm{T}}$ was suspended in $10 \%$ glycerol solution and stored at $-80^{\circ} \mathrm{C}$.

\section{Morphological and physiological characteristics}

The cultural characteristics of strain $\mathrm{ST} 13^{\mathrm{T}}$ were observed on ISP media at $28^{\circ} \mathrm{C}$ for 5 days. Morphological features were observed under a scanning electron microscope (JSM-6060; JEOL, Tokyo, Japan). ${ }^{13}$ Cell motility was tested under a light microscope by observing cells suspended in phosphate buffer (1 mM; pH 7.0). Gram staining was performed using Hucker's modification. ${ }^{14}$ Growth under anaerobic conditions was determined by incubating in an anaerobic chamber with an $\mathrm{O}_{2}$-absorbing and $\mathrm{CO}_{2}$-generating agent (Anaero-Pack; Mitsubishi Gas Chemical Company, INC., Tokyo, Japan). Growth tests for $\mathrm{pH}$ range were carried out by using media adjusted to $\mathrm{pH} 3-12$ with $4 \mathrm{M}$ $\mathrm{HCl}$ or $5 \mathrm{M} \mathrm{KOH}$ after sterilization, and $\mathrm{NaCl}$ tolerance was examined on $\mathrm{YS}$ medium supplemented with $1-10 \% \mathrm{NaCl}(\mathrm{w} / \mathrm{v})$ after $1-5$ days of incubation at $28^{\circ} \mathrm{C}$. The optimum temperature and temperature range for growth were determined by incubating at $5,10,15,20,25,28,37,45$ and $50^{\circ} \mathrm{C}$. ISP medium 8 was used to test for nitrate reduction. ${ }^{15}$ Decomposition of urea was determined on Christensen urea agar containing 2.0\% urea. ${ }^{16}$ Degradation of casein and other compounds (final concentration 0.5\%) was determined using nutrient agar as the basal medium. ${ }^{16}$ Catalase activity was determined by production of bubbles after the addition of a drop of $3.0 \% \mathrm{H}_{2} \mathrm{O}_{2}$. Oxidase activity was examined using cytochrome oxidase paper (Nissui Pharmaceutical CO., Tokyo, Japan). Other physiological and biochemical characteristics were determined by using API ZYM, API Coryne and API 50CH systems (bioMérieux, Marcy l'Etoile, France) according to the manufacturer's instructions.

${ }^{1}$ NITE Biological Resource Center, National Institute of Technology and Evaluation, Chiba, Japan and ${ }^{2}$ Tokyo University of Technology, Tokyo, Japan Correspondence: Dr M Otoguro, NITE Biological Resource Center, National Institute of Technology and Evaluation, Kazusakamatari 2-5-8, Kisarazu, Chiba 292-0818, Japan. E-mail: otoguro-misa@nite.go.jp

Received 11 January 2011; revised 31 May 2011; accepted 15 June 2011; published online 3 August 2011 

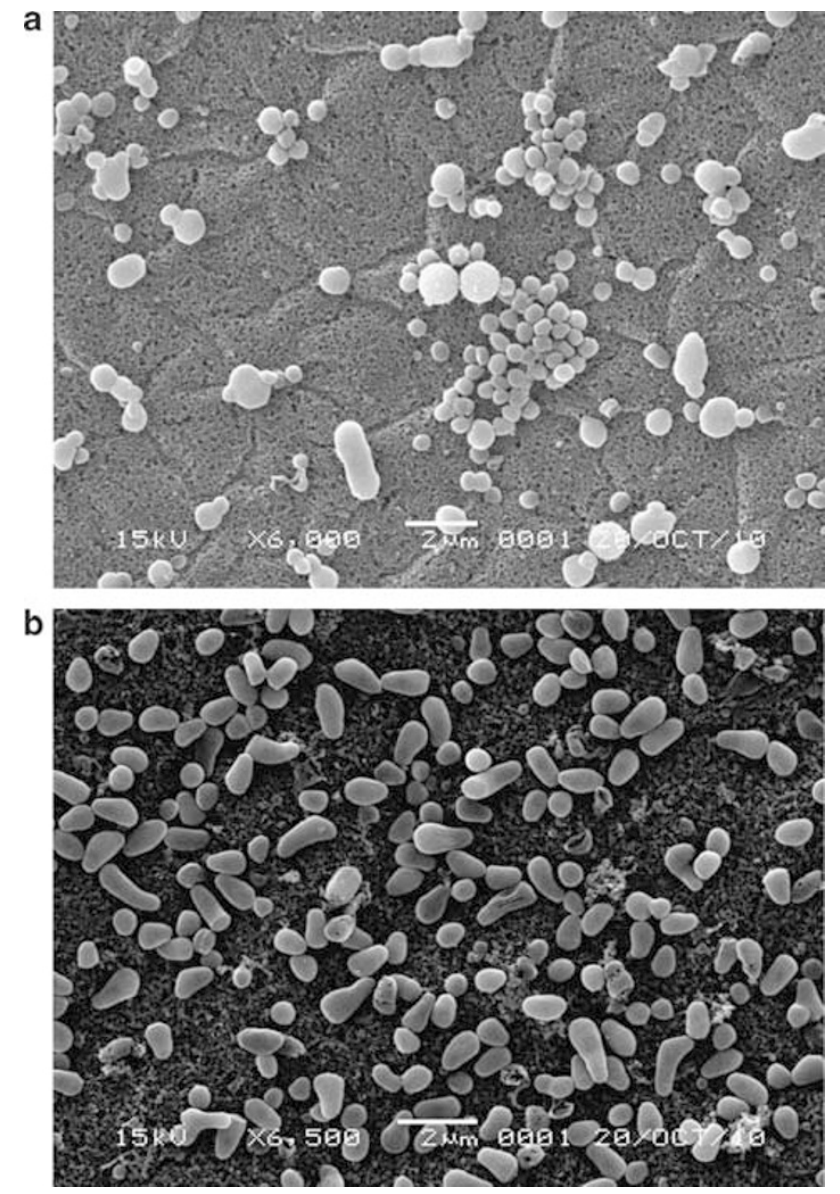

Chemotaxonomic analysis

Strain $\mathrm{ST} 13^{\mathrm{T}}$ was subjected to chemotaxonomic analysis for its classification in the family Dermacoccaceae, including menaquinones, ${ }^{13}$ polar lipids, ${ }^{17}$ wholecell sugars ${ }^{18}$ and DNA G+C content. ${ }^{19}$ Analysis of cellular fatty acids was carried out using the Microbial Identification System version 4.02 (MIDI, Inc., Newark, DE, USA), ${ }^{20}$ and the results were compared with the ACTINO library in the Microbial Identification System. Cell-wall amino acids were analyzed by using the method described by Tamura et al., ${ }^{13}$ and the amino acid isomers in cell-wall peptidoglycan were analyzed using the method described by Nozawa et al. ${ }^{21}$ Biomass for chemotaxonomic studies was obtained by cultivation in shaken flasks containing YG broth (10 g glucose, $10 \mathrm{~g}$ yeast extract and $15 \mathrm{gl}^{-1}$ agar; $\mathrm{pH} 7.3$ ) for $24-72 \mathrm{~h}$ at $28^{\circ} \mathrm{C} .^{22}$

\section{Phylogenetic analysis}

DNA extraction from strain ST13 ${ }^{\mathrm{T}}$ and PCR amplification of the 16S rRNA gene were performed as described by Tamura and Hatano. ${ }^{23}$ PCR product was directly sequenced using a BigDye Terminator v3.1 Cycle Sequencing Kit (Applied Biosystems, Foster City, CA, USA) and an automatic DNA sequencer (ABI Prism 3730 Genetic Analyzer; Applied Biosystems).

The CLUSTAL_X program ${ }^{24}$ was used to align the 16S rRNA gene sequences with related sequences (available in the GenBank/EMBL/DDBJ databases) from all of the type strains of the family Dermacoccaceae. Phylogenetic trees were constructed by the neighbor-joining ${ }^{25}$ and maximum-likelihood ${ }^{26}$ methods using MEGA (Molecular Evolutionary Genetics Analysis) version 3.1. ${ }^{27}$ The topology of the tree was evaluated by means of bootstrap analysis based on 1000 replicates. $^{28}$

Figure 1 Scanning electron micrographs of irregular coccoid or commashaped cells from 1-week-old cultures of strain $\mathrm{ST}_{1}{ }^{\top}$ grown on 1/2 ISP2 (a) and ISP2 (b).

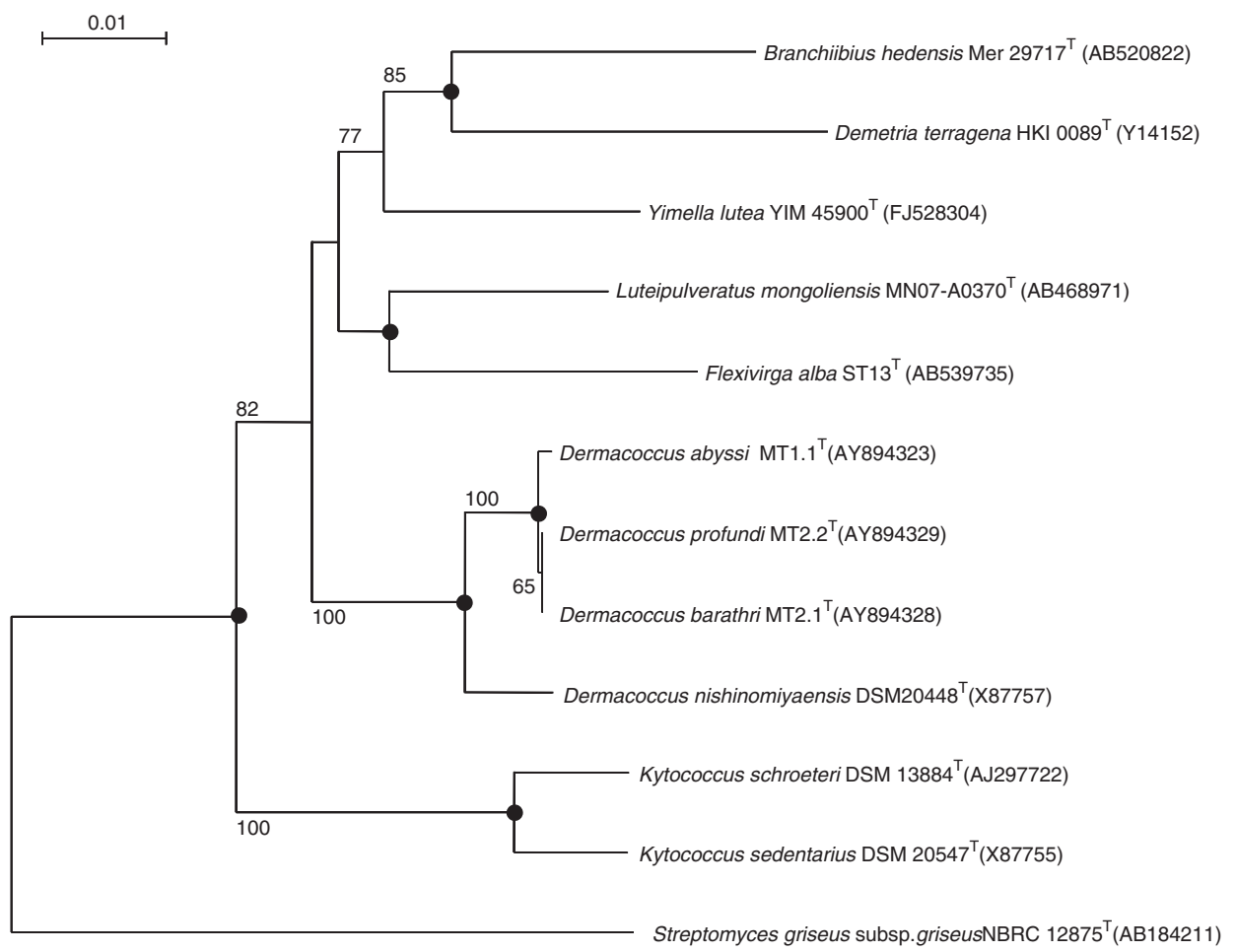

Figure 2 Phylogenetic tree based on 16S rRNA gene sequences constructed with the neighbor-joining algorithm showing the relationships between strain $\mathrm{ST}_{1} \mathrm{3}^{\mathrm{T}}$ and members of the family Dermacoccaceae. Numbers at branch points are confidence limits estimated with bootstrap analysis based on 1000 replicates; only values of $50 \%$ are presented. Solid circles indicated that the corresponding nodes were also recovered in maximum-likelihood algorithms. Bar, $0.01 K_{\text {nuc }}$ in nucleotide sequences. 


\section{RESULTS AND DISCUSSION}

\section{Morphological and physiological characteristics}

Strain $\mathrm{ST} 13^{\mathrm{T}}$ formed moist, smooth and white colonies on ISP medium 2 and YS medium. The cells were aerobic, Gram-positive, catalase-negative, oxidase-negative, non-sporulating and non-motile. Mycelia had not developed. Strain $\mathrm{ST} 13^{\mathrm{T}}$ exhibited good growth in $\mathrm{NaCl}$ concentrations of up to $5.0 \%$ and weak growth at $6.0 \%$. Good growth was observed at $15-37^{\circ} \mathrm{C}$, and no growth at $5{ }^{\circ} \mathrm{C}$ and $50{ }^{\circ} \mathrm{C}$. The optimum temperature for growth was $25^{\circ} \mathrm{C}$. The $\mathrm{pH}$ range for growth was 5.0-9.0 and the optimum was 7.0-8.0. The strain grew well on ISP medium 2, 3, 5, 6 and 7, but grew weakly on ISP medium 4. Scanning electron microscopy revealed near-coccoid cells $(0.6-$ $1.2 \mu \mathrm{m}$ in diameter) with buds on $1 / 2$ ISP medium $2(2 \mathrm{~g}$ yeast extract, $5 \mathrm{~g}$ malt extract, $2 \mathrm{~g}$ dextrose and $15 \mathrm{gl}^{-1}$ agar; $\mathrm{pH} 7.3$ ) (Figure 1a). However, there seemed to be near-comma shaped cells that varied in size $(0.5-0.8 \times 1.2-1.8 \mu \mathrm{m})$ on ISP medium 2 without budding cells (Figure 1b). From the initial stage of cultures, commashaped cells were observed on ISP medium 2. It revealed that the cell morphology did not depend on culture stage. Other physiological and biochemical characteristics are shown in the species description.

\section{Chemotaxonomic characteristics}

Strain $\mathrm{ST}_{1} 3^{\mathrm{T}}$ contained ribose, glucose, galactose, rhamnose and mannose as whole-cell sugars. The predominant menaquinone was MK- $8\left(\mathrm{H}_{4}\right)$, whereas the minor component was MK- $8\left(\mathrm{H}_{6}\right)$. Purified peptidoglycan of strain $\mathrm{ST} 13^{\mathrm{T}}$ contained glutamic acid, serine, glycine, alanine and lysine in a molar ratio of 2.0:1.8:1.1:1.8:0.7, respectively. Enantiomeric analysis of the peptidoglycan amino acids revealed the presence of D-Ala, L-Ala, D-Glu, L-Ser and L-Lys. These data indicated that the cell-wall peptidoglycan of strain ST13 ${ }^{\mathrm{T}}$ was of the A4 $\alpha$ type, ${ }^{29}$ with L-Lys as the diagnostic cell-wall diamino acid, and the interpeptide bridge of the peptidoglycan contained D-Glu, glycine and L-Ser (two molecules). Although the interpeptide bridge structure is similar to that of the genus Dermacoccus, strain ST13 ${ }^{\mathrm{T}}$ differs from the genus Dermacoccus based on the presence of a glycine residue. The major cellular fatty acid was iso- $\mathrm{C}_{16: 0}(58.5 \%)$, and minor components were iso- $\mathrm{C}_{16: 1} \mathrm{H}$ (9.4\%), $\mathrm{C}_{16: 0}$ 10-methyl (4.8\%), anteiso- $\mathrm{C}_{17: 0}(4.3 \%)$, iso- $\mathrm{C}_{16: 0} 2 \mathrm{OH}(4.2 \%), \mathrm{C}_{16: 1}$ cis 9 (3.2\%), anteiso- $\mathrm{C}_{17: 1} \mathrm{C}(2.9 \%), \mathrm{C}_{17: 0}$ 10 -methyl $(2.7 \%)$, iso- $\mathrm{C}_{14: 0}(1.8 \%)$, iso- $\mathrm{C}_{18: 0}(1.6 \%), \mathrm{C}_{16: 0}(1.6 \%)$, iso- $\mathrm{C}_{17: 0}(1.1 \%)$ and iso- $\mathrm{C}_{15: 0}(1.1 \%)$. The polar lipid detected was phosphatidylglycerol, and the DNA G+C content was $67.4 \mathrm{~mol} \%$.

\section{Phylogenetic characteristics}

An almost-complete $16 \mathrm{~S}$ rRNA gene sequence (1483 nt) was determined for strain ST13 ${ }^{\mathrm{T}}$. The GenBank/EMBL/DDBJ accession number for the 16S rRNA gene sequence of strain $\mathrm{ST}_{13}^{\mathrm{T}}$ is $\mathrm{AB} 539735$. Comparative 16S rRNA gene sequence analysis revealed that the strain ST13 ${ }^{\mathrm{T}}$ belonged to the suborder Micrococcineae and its closest phylogenetic neighbors were members of the genera within the family Dermacoccaceae (Figure 2). The similarity values of the $16 \mathrm{~S}$ rRNA gene sequences between strain $\mathrm{ST} 13^{\mathrm{T}}$ and members of the genera Demetria, Dermacoccus, Kytococcus, Luteipulveratus, Yimella and Branchiibius ranged from 93.1 to $95.1 \%$.

On the basis of phylogenetic analysis of 16S rRNA gene sequences, strain $\mathrm{ST} 13^{\mathrm{T}}$ was closely related to members of the genera in the family Dermacoccaceae, and formed a monophyletic branch within the radius occupied by the family. Its closest phylogenetic neighbor was Luteipulveratus mongoliensis $\mathrm{MN} 07-\mathrm{A} 0370^{\mathrm{T}}$ (95.1\%), which differed from the isolate by amino acids, polar lipids and cell morphology (Table 1). Obvious differences in chemotaxonomic, morphological and physiological properties were also found between $\mathrm{ST} 13^{\mathrm{T}}$ and members of

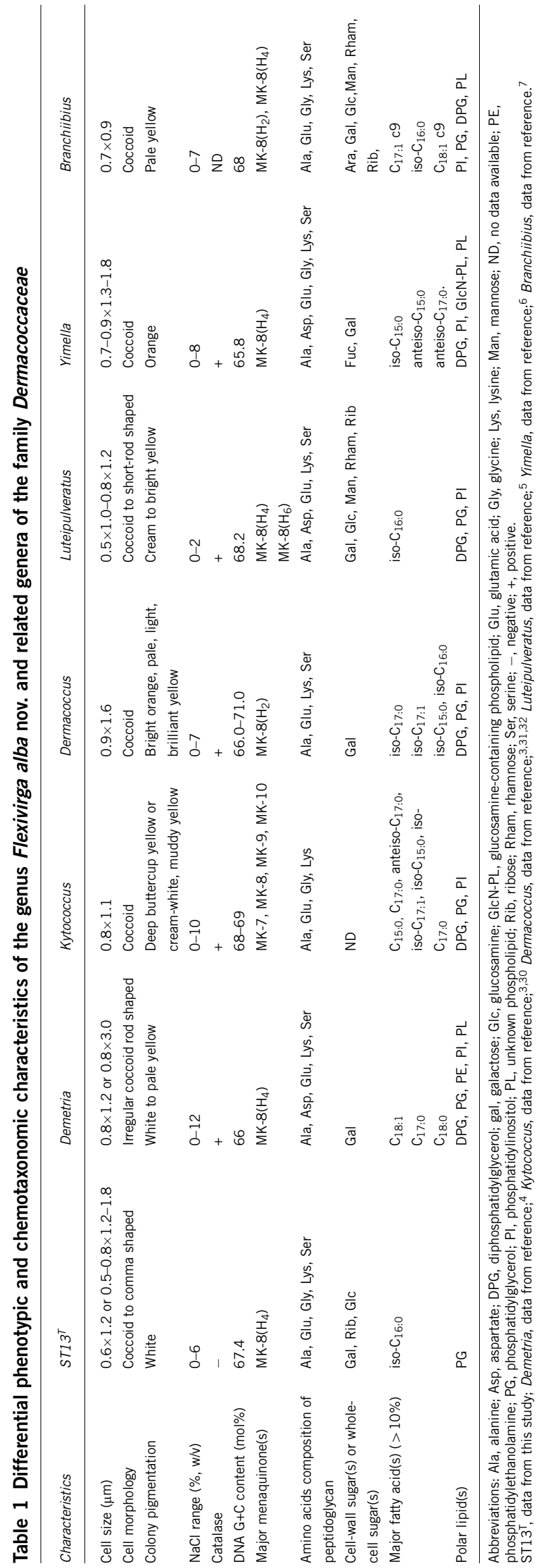


other genera in the family Dermacoccaceae. On the basis of its chemotaxonomic characteristics and phylogenetic analysis, strain $\mathrm{ST} 13^{\mathrm{T}}$ represents a novel genus and species in the family Dermococcacae, for which the name Flexivirga alba gen. nov., sp. nov. is proposed.

\section{Description of Flexivirga gen. nov.}

Flexivirga (fle.xi.vir'ga. L. adj. flexus, bent; L. fem. n. virga, a rod; N.L. fem. n. Flexivirga, a bent rod). Cells are Gram-positive, irregular coccoid or comma-shaped, non-motile, aerobic and non-sporulating. The cell-wall peptidoglycan is of the A4 $\alpha$ type with L-lysine as the diamino acid. The predominant menaquinone is $\mathrm{MK}-8\left(\mathrm{H}_{4}\right)$ and the major polar lipid is phosphatidylglycerol. Whole cells contain ribose, glucose and galactose as major components, with rhamnose and mannose as minor components. The major cellular fatty acid is iso- $\mathrm{C}_{16: 0}$. The $\mathrm{G}+\mathrm{C}$ content of the type species is $\sim 67 \mathrm{~mol} \%$. Phylogenetically, the genus Flexivirga belongs to the family Dermacoccaceae. The type species is F. alba.

\section{Description of $F$. alba sp.nov}

F. alba (al'ba. L. fem. adj. alba, white, referring to the color of the colonies) displays the following properties in addition to those given for the genus: catalase-negative, oxidase-negative, growth occurs with $\mathrm{NaCl}$ concentrations of $0-6 \%$, grows at $10-45^{\circ} \mathrm{C}$ (optimum temperature, $25^{\circ} \mathrm{C}$ ) and $\mathrm{pH}$ 5.0-9.0 (optimum $\mathrm{pH}, 7.0-8.0$ ), xanthine and hypoxanthine are decomposed, but not casein, calcium malate, tyrosine or adenine. According to the API $50 \mathrm{CH}$ test, acid is produced from $\mathrm{N}$-acetylglucosamine, D-cellobiose, D-glucose, D-arabinose, D-ribose, D-xylose, D-arabinose, glycerol, L-rhamnose, D-mannitol, D-sucrose, D-trehalose, D-turanose, D-lyxose, D-fucose, D-arabitol and 5-ketogluconate, but all very weakly. According to the API ZYM enzyme assay, the strain is positive for alkaline phosphatase, leucine arylamidase, valine arylamidase, $N$-acetyl- $\beta$-glucosaminidase, naphthol AS-BI phosphohydrolase, cystine arylamidase, trypsin and acid phosphatase. It is also weakly positive for $\alpha$-fucosidase, $\beta$-galactosidase, and negative for esterase (C4), esterase lipase (C8), lipase (C14), $\alpha$-chymotrypsin, $\alpha$-galactosidase, $\alpha$-mannosidase, $\beta$-glucuronidase and $\beta$-glucosidase. According to the API Coryne enzyme assay, it is positive for alkaline phosphatase, pyrazin amidase, $\beta$-galactosidase, $\alpha$-glucosidase and $N$-acetyl- $\beta$-glucosaminidase, and negative for pyrrolidonyl arylamidase and $\beta$-glucuronidase. Nitrate is reduced. Aesculin and gelatin are hydrolyzed, but urea is not. The minor component of fatty acids are iso- $\mathrm{C}_{16: 1} \mathrm{H}, \mathrm{C}_{16: 0}$ 10-methyl, anteiso- $\mathrm{C}_{17: 0}$, iso- $\mathrm{C}_{16: 0} \quad 2 \mathrm{OH}, \mathrm{C}_{16: 1}$ cis 9 , anteiso- $\mathrm{C}_{17: 1} \mathrm{C}, \mathrm{C}_{17: 0}$ 10-methyl, iso- $\mathrm{C}_{14: 0}$, iso- $\mathrm{C}_{18: 0}, \mathrm{C}_{16: 0}$, iso- $\mathrm{C}_{17: 0}$. The $\mathrm{DNA} \mathrm{G}+\mathrm{C}$ content of the type strain is $67.4 \mathrm{~mol} \%$. The type strain ST13 ${ }^{\mathrm{T}}$ (=NBRC $107580^{\mathrm{T}}=$ DSM $24460^{\mathrm{T}}$ ) was isolated from soil in Japan.

\section{ACKNOWLEDGEMENTS}

We thank Dr Tomohiko Tamura and Mr Moriyuki Hamada for their scientific discussions. We are also grateful to Dr JP Euzéby for the Latin construction of the generic name.

1 Stackebrandt, E. \& Schumann, P. Description of Bogoriellaceae fam. nov., Dermacoccaceae fam. nov., Rarobacteraceae fam. nov. and Sanguibacteraceae fam. nov. and emendation of some families of the suborder Micrococcineae. Int. J. Syst. Evol. Microbiol. 50, 1279-1285 (2000).

2 Zhi, X.- Y., Li, W.- J. \& Stackebrandt, E. An update of the structure and 16S rRNA gene sequence-based definition of higher ranks of the class Actinobacteria, with the proposal of two new suborders and four new families and emended descriptions of the existing higher taxa. Int. J. Syst. Evol. Microbiol. 59, 589-608 (2009).
3 Stackebrandt, E., Koch, C., Gvozdiak, O. \& Schumann, P. Taxonomic dissection of the genus Micrococcus: Kocuria gen. nov., Nesterenkonia gen. nov., Kytococcus gen. nov., Dermacoccus gen. nov., and Micrococcus Cohn 1872 gen. emend. Int. J. Syst. Bacteriol. 45, 682-692 (1995).

4 Groth, I. et al. Demetria terragena gen. nov., sp. nov., a new genus of actinomycetes isolated from compost soil. Int. J. Syst. Evol. Microbiol. 47, 1129-1133 (1997).

5 Ara, I., Yamamura, H., Tsetseg, B., Daram, D. \& Ando, K. Luteipulveratus mongoliensis gen. nov., sp. nov., an actinobacterial taxon in the family Dermacoccaceae. Int. J. Syst. Evol. Microbiol. 60, 574-579 (2010).

6 Tang, S., Wu, J., Wang, Y., Schumann, P. \& Li, W. Yimella lutea gen. nov., sp. nov., a novel actinobacterium of the family Dermacoccaceae. Int. J. Syst. Evol. Microbiol. 60, 659-663 (2010).

7 Sugimoto, S. et al. Branchiibius hedensis gen. nov., sp. nov., an actinobacterium isolated from a codfish Physiculus japonicus. Int. J. Syst. Evol. Microbiol. 61, 1195 (2011).

8 De la Rosa, M. C., Mohino, M. R., Mohino, M. \& Mosso, M. A. Characteristics of micrococci and staphylococci isolated from semi-preserved meat products. Food Microbiol. 7, 207-215 (1990).

9 Cordero, M. R. \& Zumalacárregui, J. M. Characterization of Micrococcaceae isolated from salt used for Spanish dry-cured ham. Lett. Appl. Microbiol. 31, 303-306 (2000).

10 Becker, K. et al. Kytococcus schroeteri sp. nov., a novel Gram-positive actinobacterium isolated from a human clinical source. Int. J. Syst. Evol. Microbiol. 52, 1609-1614 (2002).

11 Papamanoli, E., Kotzekidou, P., Tzanetakis, N. \& Litopoulou-Tzanetaki, E. Characterization of Micrococcaceae isolated from dry fermented sausage. Food Microbiol. 19, 441-449 (2002).

12 Shirling, E. B. \& Gottlieb, D. Methods for characterization of Streptomyces species. Int. J. Syst. Bacteriol. 16, 313-340 (1966).

13 Tamura, T. et al. A new genus of the order Actinomycetales, Couchioplanes gen. nov., with descriptions of Couchioplanes caeruleus (Horan and Brodsky 1986) comb. nov. and Couchioplanes caeruleus subsp. azureus subsp. nov. Int. J. Syst. Bacteriol. 44, 193-203 (1994).

14 Gerhardt, P., Murray, R. G. E., Wood, W. A. \& Krieg, N. R. Methods for General and Molecular Bacteriology (American Society for Microbiology, Washington, DC, 1994).

15 Gordon, R. E. \& Mihm, J. M. A comparative study of some strains received as nocardiae. J. Bacteriol. 73, 15-27 (1957).

16 Gordon, R. E., Barnett, D. A., Handerhan, J. E. \& Pang, C. H.- N. Nocardia coeliaca, Nocardia autotrophica, and the nocardin strain. Int. J. Syst. Bacteriol. 24, 54-63 (1974)

17 Minnikin, D. E., Collins, M. D. \& Goodfellow, M. Fatty acid and polar lipid composition in the classification of Cellulomonas, Oerskovia and related taxa. J. Appl. Microbiol. 47, 87-95 (1979).

18 Staneck, J. L. \& Roberts, G. D. Simplified approach to identification of aerobic actinomycetes by thin-layer chromatography. Appl. Environ. Microbiol. 28, 226-231 (1974).

19 Mesbah, M., Premachandran, U. \& Whitman, W. B. Precise measurement of the G+C content of deoxyribonucleic acid by high-performance liquid chromatography. Int. J. Syst. Bacteriol. 39, 159-167 (1989).

20 Sasser, M. Identification of Bacteria by Gas Chromatography of Cellular Fatty Acids, MIDI Technical Note 101 (MIDI Inc., Newark, DE, 1990).

21 Nozawa, Y., Sakai, N., Arai, K., Kawasaki, Y. \& Harada, K. Reliable and sensitive analysis of amino acids in the peptidoglycan of actinomycetes using the advanced Marfey's method. J. Microbiol. Methods 70, 306-311 (2007).

22 Sakiyama, Y. et al. Kineosporia babensis sp. nov., isolated from plant litter in Vietnam. Int. J. Syst. Evol. Microbiol. 59, 550-554 (2009).

23 Tamura, T. \& Hatano, K. Phylogenetic analysis of the genus Actinoplanes and transfer of Actinoplanes minutisporangius Ruan et al. 1986 and 'Actinoplanes aurantiacus' to Cryptosporangium minutisporangium comb. nov. and Cryptosporangium aurantiacum sp. nov. Int. J. Syst. Evol. Microbiol. 51, 2119-2125 (2001).

24 Thompson, J. D., Gibson, T. J., Plewniak, F., Jeanmougin, F. \& Higgins, D. G. The CLUSTAL_X Windows interface: flexible strategies for multiple sequence alignment aided by quality analysis tools. Nucleic Acids Res. 25, 4876-4882 (1997).

25 Saitou, N. \& Nei, M. The neighbor-joining method: a new method for reconstructing phylogenetic trees. Mol. Biol. Evol. 4, 406-425 (1987).

26 Felsenstein, J. Evolutionary trees from DNA sequences: a maximum likelihood approach. J. Mol. Evol. 17, 368-376 (1981).

27 Kumar, S., Tamura, K. \& Nei, M. MEGA3: integrated software for molecular evolutionary genetics analysis and sequence alignment. Brief Bioinform 5, 150-163 (2004).

28 Felsenstein, J. Confidence limits on phylogenies: an approach using the bootstrap. Evolution 39, 783-791 (1985).

29 Schleifer, K. H. \& Kandler, O. Peptidoglycan types of bacterial cell walls and their taxonomic implications. Bacteriol. Rev. 36, 407-477 (1972).

30 Becker, K. et al. Kytococcus schroeteri sp. nov., a novel Gram-positive actinobacterium isolated from a human clinical source. Int. J. Syst. Evol. Microbiol. 52, 1609-1614 (2002).

31 Pathom-aree, W. et al. Dermacoccus abyssi sp. nov., a piezotolerant actinomycete isolated from the Mariana Trench. Int. J. Syst. Evol. Microbiol. 56, 1233-1237 (2006).

32 Pathom-aree, W. et al. Dermacoccus barathri sp. nov. and Dermacoccus profundi sp. nov., novel actinomycetes isolated from deep-sea mud of the Mariana Trench. Int. J. Syst. Evol. Microbiol. 56, 2303-2307 (2006). 